Wyk, J. J.: Characterization of the insulin and somatomedin-C receptors in human placental cell membranes. J. Clin. Endocrinol. Metab., 39: 283 (1974).

13. Meschia, G., Battaglia, F. C., and Bruns, P. D.: Theoretical and experimental study of transplacental diffusion. J. Appl. Physiol., 22: 1171 (1967).

14. Rabain, F., and Pison, L.: Effect of insulin on the materno-fetal transfer of glucose in the rat. Hormone Metab. Res., 6: 376 (1974).

15. Remington, R. D., and Schork, M. A.: Statistics with Application to the Biological and Health Sciences, p. 213 (Prentice Hall, Englewood, NJ, 1970).

16. Simmons, M. A., Meschia, G., Makowski, E. L., and Battaglia, F. C.: Fetal metabolic response to maternal starvation. Pediat. Res., 8: 830 (1974).

17. Sols, A., and de la Fuente, G.: Hexokinase and other enzymes of sugar metabolism in the intestine. In: J. H. Quastel: Methods in Medical Research, Vol. 9, pp. 302-309 (Year Book Publishers, Chicago, 1961).

0031-3998/78/1202-0090\$02.00/0

Copyright $(0) 1978$ International Pediatric Research Foundation, Inc.
18. Szabo, A. J., and Grimaldi, R. D.: The effect of insulin on glucose metabolism of the incubated human placenta. Amer. J. Obstet. Gynecol., 106: 75 (1970).

19. Villee, C. A.: The metabolism of human placenta in vitro. J. Biol. Chem., 205: 113 (1953).

20. Michael A. Simmons, M.D., is an Established Investigator of the American Heart Association.

21. This research was supported by NIH Grants HD-00781, HD-01866 and a Basil O'Connor Starter Research Grant from the National Foundation March of Dimes.

22. Requests for reprints should be addressed to: M. A. Simmons, M.D., University of Colorado, Medical Center, 4200 East Ninth Ave., Denver, CO 80220 (USA).

23. Received for publication February 22, 1977.

24. Accepted for publication May 6, 1977

Printed in U.S.A.

Pediat. Res. 12: 92-94 (1978)

Light patent ductus arteriosus

oxygen photochemistry

\title{
Patent Ductus Arteriosus: A New Light on an Old Problem
}

\author{
RONALD I. CLYMAN ${ }^{(23)}$ AND ABRAHAM M. RUDOLPH \\ Cardiovascular Research Institute and the Departments of Pediatrics and Obstetrics, Gynecology and Reproductive \\ Sciences, University of California, San Francisco, California, USA
}

\section{Summary}

It has been suggested previously that delayed closure of the ductus arteriosus in premature infants is related to an ineffective constriction in response to an increase in arterial $\mathbf{P O}_{2}$. The contractile effects of increased $\mathrm{PO}_{2}$ and excess $\mathrm{K}^{+}$were studied in rings of ductus arteriosus from early $(70 \pm 4$ days, $n=9)$ and late (137 \pm 3 days, $n=11)$ gestation fetal lambs. Studies were performed in a laboratory using overhead fluorescent lighting or in a dark, enclosed box. Room light relaxed the oxygen-induced contraction in immature vessels but had no significant effect on the $\mathrm{K}^{+}$-induced contraction. Room light did not alter either the oxygen or $\mathrm{K}^{+}$-induced contractile responses in mature vessels. When comparing oxygen induced contractions in room light in immature vessels $(0.27 \pm 0.13 \mathrm{~g}, n=9)$ vs. mature vessels $(0.82 \pm 0.06 \mathrm{~g}, n=11)$ there appeared to be an increased response to oxygen with advancing gestational age. However, when the oxygen-induced responses of immature $(0.59 \pm 0.15 \mathrm{~g}, n=9)$ and mature $(0.82 \pm 0.06 \mathrm{~g}, n=11)$ vessels were performed in an environment excluding room light, no significant gestational difference was observed. The role of oxygen in delayed closure of the ductus arteriosus of premature infants will need further evaluation.

\section{Speculation}

The difference in sensitivity to photorelaxation between rings of ductus arteriosus from immature and mature lambs may be associated with biochemical differences in vessels between early and late gestation.

In contrast to full-term infants in whom functional closure of the ductus arteriosus occurs within the first $24 \mathrm{hr}$ after birth, preterm infants frequently have delayed spontaneous closure
(3). The exact mechanism responsible for the constriction of the ductus arteriosus at birth and for its delay in closure in preterm infants is as yet unknown. Numerous observations have drawn attention to the importance of the postnatal increase in arterial oxygen pressure $\left(\mathrm{PO}_{2}\right)$ for muscular closure of the ductus arteriosus $(6,11,13,14)$. Rudolph (18) has suggested that the higher incidence of patent ductus arteriosus in preterm infants might be due to immaturity of ductal smooth muscle. Several in vitro studies have suggested that delayed closure of the ductus arteriosus in preterm infants is related to an ineffective constriction in response to increases of $\mathrm{PO}_{2}(10,14,15)$. This development of responsiveness to $\mathrm{O}_{2}$ has been attributed to maturation of either specific receptors for oxygen (15) or vascular smooth muscle contractility $(10)$. The results reported below identify a third possible explanation for this in vitro developmental response of the ductus arteriosus to oxygen. Several years ago Furchgott et al. (9) observed a photoactivated relaxation of smooth muscle in isolated strips of rabbit aorta. This relaxation was reversible, depended on the pre-exposure level of active contraction, and occurred in the presence or absence of oxygen. We have observed that vessels from immature lambs are very sensitive to photorelaxation by overhead fluorescent lights, used for general illumination in the laboratory, whereas those from older lambs are insensitive. We suggest that the lack of responsiveness to oxygen of immature vessels in vitro may be secondary to the effects of overhead laboratory lights on immature vessels and that there may be minimal gestational differences in contractile response to oxygen.

\section{MATERIALS AND METHODS}

Time-dated fetal lambs, between 56 and 145 days of gestational age (term is 150 days), were delivered by cesarean 
section and rapidly killed by exsanguination. The ductus arteriosus was dissected free from adventitial tissue and divided into $2 \mathrm{~mm}$ thick rings which were placed in separate $150 \mathrm{ml}$ isolated Lucite plastic organ baths (fluid removed by draining). The rings were suspended under an initial load of $1 \mathrm{~g}$ between two stainless steel hooks, in a solution containing $127 \mathrm{mM} \mathrm{NaCl}, 5$ $\mathrm{mM} \mathrm{KCl}, 2.7 \mathrm{mM} \mathrm{CaCl}, 1.27 \mathrm{mM} \mathrm{MgCl} \mathrm{M}_{2} \cdot 6 \mathrm{H}_{2} \mathrm{O}, 5.5 \mathrm{mM}$ glucose, and $50 \mathrm{mM}$ Tris $\cdot \mathrm{HCl}, \mathrm{pH} 7.39$ at $37^{\circ}$. Isometric responses were measured by a Grass FT $03 \mathrm{C}$ force transducer and recorded on a Grass polygraph. Small samples of the bathing solution were withdrawn and $\mathrm{pH}$ and $\mathrm{PO}_{2}$ were measured using Radiometer electrodes and blood gas meter.

General illumination in the laboratory was kept constant throughout the duration of the studies. The laboratory was illuminated from recessed ceiling fixtures containing $\mathrm{F} 40 \mathrm{CW}$ Cool White General Electric fluorescent lamps which were filtered through a $2 \mathrm{~mm}$ thickness of acrylic plastic. Overhead lighting was $132 \mathrm{~cm}$ above the suspended tissues. The illumination reading at the organ bath, as recorded on a light meter (Weston Electric Instrument Corporation, Newark, NJ) was 77 footcandles (12).

The bathing solution in each bath was bubbled with $100 \% \mathrm{~N}_{2}$ (to a $\mathrm{PO}_{2}$ of 14-20 torr) and the rings allowed to equilibrate for 1-2 hr until a steady tension was developed. The rings were exposed to $100 \% \mathrm{O}_{2}$ (to a $\mathrm{PO}_{2}$ of $680-720$ torr) for 30-50 min, allowing the tension to achieve a new plateau. The vessels then were allowed to relax in $100 \% \mathrm{~N}_{2}$. The organ baths were placed in the dark by an enclosed box and the tissues allowed to reach a new steady tension. A second oxygen response was obtained in the dark and the vessels subsequently were allowed to relax in the dark in $100 \% \mathrm{~N}_{2}$. The box then was removed exposing the tissues to room light and, after a steady tension was achieved in $100 \% \mathrm{~N}_{2}$, a third oxygen challenge was performed. The sequence of light exposures was randomized among the different vessels so that in some vessels the order of oxygen challenges were done in the dark followed by light followed by dark.

The effects of light on $\mathrm{K}^{+}$-induced contractions were examined in some tissues. Rings of ductus arteriosus were suspended in the above high $\mathrm{Na}^{+}$solution and allowed to reach a steady tension in $100 \% \mathrm{O}_{2}$ in room light. The bath solution was rapidly exchanged with a new high $\mathrm{K}^{+}$solution $(42 \mathrm{mM} \mathrm{NaCl}$, $90 \mathrm{mM} \mathrm{KCl}, 2.7 \mathrm{mM} \mathrm{CaCl}, 1.27 \mathrm{mM} \mathrm{MgCl} \cdot 6 \mathrm{H}_{2} \mathrm{O}, 5.5 \mathrm{mM}$ glucose, and $50 \mathrm{mM}$ Tris $\cdot \mathrm{HCl}, \mathrm{pH} 7.39, \mathrm{PO}_{2} 680-720$ torr, $37^{\circ}$ ) and allowed to reach a steady tension. The solution bathing the tissue was changed four times with high $\mathrm{Na}^{+}$solution and the tissue allowed to relax to a steady tension at $100 \% \mathrm{O}_{2}$. The organ baths then were placed in the dark in an enclosed box. After a steady tension was reached the vessel was challenged again with the high $\mathrm{K}^{+}$solution in the dark. The sequence of light and dark exposure was randomized among the different tissues.

The paired Student's $t$-test was used to compare mean tensions.

\section{RESULTS}

The response of the ductus arteriosus in room light exposed to high $\mathrm{PO}_{2}$ was similar to that reported previously (16). The response in room light to changes in $\mathrm{PO}_{2}$ increased with gestational age from a questionably significant increase in tension $(0.27 \pm 0.13 \mathrm{~g}, n=9)$ in the immature fetus to a significant contraction $(0.82 \pm 0.06 \mathrm{~g}, n=11)$ in the mature one (Fig. 1). However, when the $\mathrm{O}_{2}$-induced contraction was performed in a dark, enclosed box, no significant difference was observed in the developed tensions of immature and mature vessels, $0.59 \pm$ $0.15 \mathrm{~g}(n=9)$ and $0.82 \pm 0.06(n=11)$, respectively (Fig. 1) $(P<0.05)$.

As can be seen in Figure 1, room light relaxed both the steady tension developed in low $\mathrm{PO}_{2}$ as well as diminished the $\mathrm{O}_{2}$-induced contraction in the immature vessels. No significant relaxant effect of light was observed in the mature vessels on the tensions in either low or high $\mathrm{PO}_{2}$.

Increasing the $\mathrm{K}^{+}$concentration of the bathing solution induced a contraction in the vessels of both immature and mature gestational ages above the increased steady tension developed

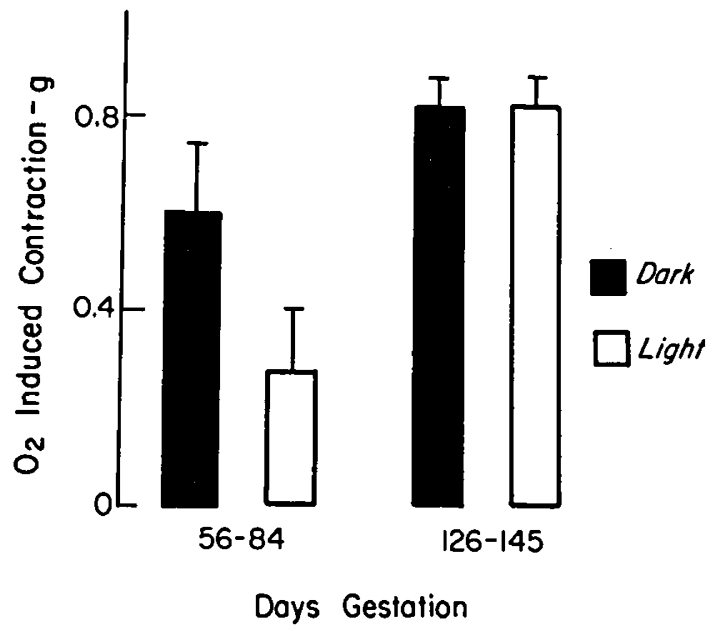

Fig. 1. Effects of light on oxygen-induced contraction in the ductus arteriosus from fetal lambs of different gestational ages. Rings of ductus arteriosus from immature lambs, 56-84 days (mean $=70 \pm 4$ days, $n=$ 9 ), and mature lambs, 126-145 days (mean $=137 \pm 3$ days, $n=11$ ), were suspended in a low $\mathrm{PO}_{2}$ (14-20 torr) solution. Some rings were exposed to general room illumination (light) and some were kept in a dark, enclosed box (dark). The initial steady tension of rings from immature vessels in low $\mathrm{PO}_{2}$ was $0.98 \pm 0.06 \mathrm{~g}$ in the dark and $0.80 \pm$ $0.08 \mathrm{~g}$ in the light $(P<0.005$, paired $t$-test $)$. The initial steady tension of rings from mature vessels in low $\mathrm{PO}_{2}$ was $1.16 \pm 0.13 \mathrm{~g}$ in the dark and $1.13 \pm 0.13 \mathrm{~g}$ in the light (no significant difference). The bar values represent the increase in tension produced by exposing the tissues to high $\left(\mathrm{PO}_{2}(680-720\right.$ torr $) \pm$ SEM. The oxygen-induced contraction is diminished in immature vessels exposed to room light $(P$ $<0.01$, paired $t$-test), but not in mature vessels.

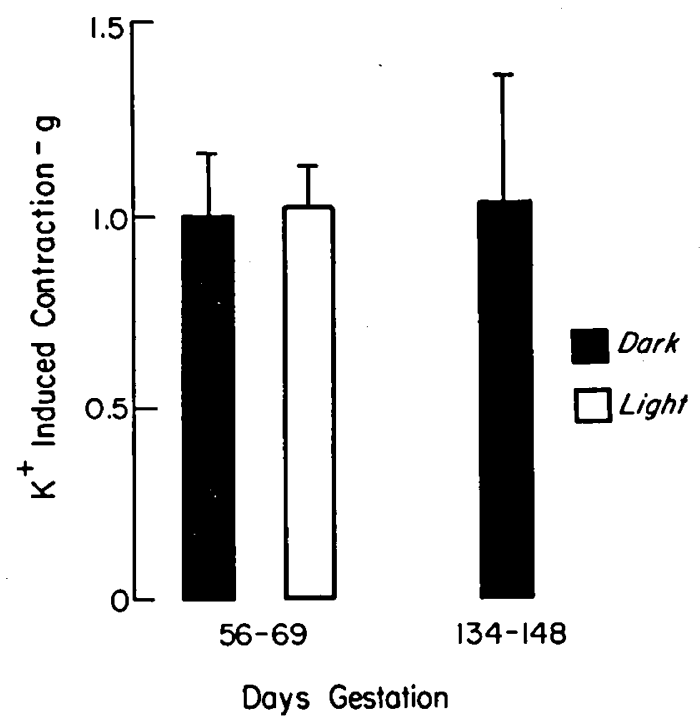

Fig. 2. Effects of light on $\mathrm{K}^{+}$-induced contraction in the ductus arteriosus from fetal lambs of different gestational ages. Rings of ductus arteriosus from immature lambs $(n=6)$ and mature lambs $(n=4)$ were suspended in a high $\mathrm{PO}_{2}$ solution (680-720 torr). Some rings were exposed to general room illumination (light) and some were kept in a dark, enclosed box (dark). The bar values represent the increase in tension produced by exposing the vessels to a solution with excess $\mathrm{KCl}$ \pm SEM. There is no significant difference between the $\mathrm{K}^{+}$-induced contraction in either immature or mature vessels or immature vessels exposed to room light. 
with high $\mathrm{PO}_{2}$ exposure. Room light had no significant effect on the $\mathrm{K}^{+}$-induced contraction in either age group (Fig. 2).

\section{DISCUSSION}

Furchgott et al. (9) observed that smooth muscle strips of rabbit aorta, placed in a state of active tonic contraction by the addition of a stimulating drug, relaxed during exposure to light. The relaxation was reversible and depended on the preexposure level of contraction. The relaxation did not require the presence of oxygen. The action spectrum reached a peak at $310 \mathrm{~nm}$ with relatively little effect at wavelengths above $450 \mathrm{~nm}$ or below $280 \mathrm{~nm}$. The extent of relaxation produced by a standard exposure was independent of the nature of the stimulating drug used to produce contraction (histamine, norepinephrine, serotonin), however, the relaxation was significantly smaller when the contraction was produced by excess $\mathrm{KCl}$.

General laboratory illumination caused photorelaxation of the ductus arteriosus from the immature lamb fetus. There was a decrease in the maximum oxygen-induced tension developed in room light. There was also no significant effect of room light on contractions induced by excess $\mathrm{KCl}$. The sensitivity of immature rings of lamb ductus arteriosus to photorelaxation appeared to be much greater than that of rabbit aorta. A significant fall in tension in the rabbit aorta was produced by radiation from a xenon arch lamp with an intensity of approximately $100 \mu \mathrm{W} / \mathrm{cm}^{2}$ at $350 \mathrm{~nm}$ (9), whereas a significant photorelaxation of the immature lamb ductus arteriosus was produced by overhead fluorescent light of less than $5 \%$ of this equivalent intensity (17). In fact, Furchgott (8) has reported that overhead fluorescent lamps do not have any significant effect on the smooth preparations he has studied.

The mechanism through which photorelaxation of the lamb ductus arteriosus occurs is unknown. Whether light activates some photosensitive material in the smooth muscle cells which leads to an alteration of the ionic permeability characteristics of the membrane $(2,4)$, to a change in cyclic nucleotide metabolism (1); to a change in cytochrome oxidation state (5), to an inactivation of surface receptors (19), to a change in prostaglandin metabolism, or to photooxidation of myoglobin (7) needs to be evaluated in the future. However, the difference in sensitivity to photorelaxation between rings of ductus arteriosus from immature and mature lambs may be associated with biochemical differences in vessels between early and late gestation.

We observed that preparations of rings of ductus arteriosus from mature lamb fetuses in vitro are not significantly relaxed by general room illumination. Similarly we observed no significant difference in the oxygen-induced contraction of immature and mature vessels kept in a dark environment. On the basis of these results we would suggest that former experiments demonstrating a diminished contractile response to $\mathrm{PO}_{2}$ in rings of ductus arteriosus from immature lambs may be secondary to the significant photorelaxation produced by general laboratory lighting rather than to an immature developmental response to oxygen.

Whether the diminished oxygen-induced contraction in in vitro preparations of ductus arteriosus from immature guinea pig is due also to a similar mechanism remains to be seen $(10$, 0031-3998/78/1202-0092\$02.00/0 Copyright $(\mathcal{1} 1978$ International Pediatric Research Foundation, Inc.
15). Fay (6) has reported a photorelaxation of the guinea pig ductus arteriosus. There is a diminished response to both oxygen- and norepinephrine-induced contractions in the immature vessels $(10)$, whereas there is no difference in the $\mathrm{K}^{+}$induced contractions of immature and mature vessels (15). These results are not inconsistent with the hypothesis stated above. Further experimental work will be necessary to clarify whether there is a maturation of the oxygen-induced contraction of the ductus arteriosus and whether this has a role in the persistent patency of the vessel in premature infants.

\section{REFERENCES AND NOTES}

1. Bitensky, M. W.: Activation of photoreceptor disk membrane phosphodiesterase by light and ATP. Advan. Cyclic Nucl. Res., 5: 213 (1975).

2. Brown, A. M., and Brown, H. M.: Light response of a giant aplysia neuron. J. Gen. Physiol., 62: 239 (1973).

3. Danilowicz, P., Rudolph, A. M., and Hoffman, J. I. E.: Delayed closure of the ductus in premature infants. Pediatrics, 37: 74 (1966).

4. Ehrreich, S. J., and Furchgott, R. F.: Relaxation of mammalian smooth muscles by visible and ultraviolet radiation. Nature (London), 218: 682 (1968).

5. Epel, B. L.: Inhibition of growth and respiration by visible and near visible light. In: A. C. Giese: Photophysiology, Vol. 8, p. 209 (Academic Press, New York, 1973).

6. Fay, F. S.: Guinea pig ductus arteriosus. I. Cellular and metabolic basis for oxygen sensitivity. Amer. J. Physiol., 221: 470 (1971).

7. Folin, M., Gennari, G., and Jori, G.: Photooxidation of horse and sperm whale myoglobin sensitized by the heme group. Photochem. Photobiol., 20: 357 (1974).

8. Furchgott, R. F.: Effects of various agents on photorelaxation of rabbit aortic strips. Proceedings of Symposium on Physiological and Pharmacological Vascular Neuroeffector Systems, Interlaken, 1969, p. 247 (Karger, Basel, 1971).

9. Furchgott, R. F., Ehrreich, S. J., and Greenblat, E.: The photoactivated relaxation of smooth muscle of rabbit aorta. J. Gen. Physiol., 44: 499 (1961).

10. Ikeda, M., Rubinstein, E. H., and Sonnenschein, R. R.: Development of the $\mathrm{O}_{2}$ induced contractions in the ductus arteriosus of the guinea pig. Experientia, 29: 445 (1973).

11. Kennedy, J. A., and Clark, S. L.: Observations on the physiological reactions of the ductus arteriosus. Amer. J. Physiol., 136: 140 (1942).

12. Klein, R. M.: Shedding light on the use of light. Pediatrics, 50: 118 (1972).

13. Kovalcik, V.: The response of the isolated ductus arteriosus to oxygen and anoxia. J. Physiol. (London), 169: 185 (1963).

14. McMurphey, D. M., Heymann, M. A., Rudolph, A. M., and Melmon, K. L.: Developmental changes in constriction of the ductus arteriosus: responses to oxygen and vasoactive agents in the isolated ductus arteriosus of the fetal lamb. Pediat. Res., 6: 231 (1972).

15. Noel, S., and Cassin, S.: Maturation of contractile response of ductus arteriosus to oxygen and drugs. Amer. J. Physiol., 231: 240 (1976).

16. Oberhansli-Weiss, I., Heymann, M. A., Rudolph, A. M., and Melmon, K. L.: The pattern and mechanisms of response to oxygen by the ductus arteriosus and umbilical artery. Pediat. Res., 6: 693 (1972).

17. Piltingsrud, H. V., Odland, L. T., and Fong, C. W.: An evaluation of fluorescent light sources for use in phototherapy of neonatal jaundice. Amer. Indust. Hygiene Ass. J., 36: 90 (1976).

18. Rudolph, A. M.: The changes in the circulation after birth: Their importance in congenital heart disease. Circulation, 41: 343 (1970).

19. Turpaev, T. M., and Yuzhanskaya, M. G.: Photoinactivation of cholinergic receptors in frog heart muscle. Neurosci. Behav. Physiol., 6: 369 (1973).

20. We wish to thank Ms. Louise Wong for her expert technical assistance.

21. Dr. R. I. Clyman is a trainee supported by Graduate Training Grant HL 05251 from the National Heart, Lung, and Blood Institute.

22. This research was supported by Program Project Grant HL-06285 from the National Heart, Lung, and Blood Institute.

23. Requests for reprints should be addressed to: Ronald I. Clyman, M.D., 1403-HSE, University of California, San Francisco, CA 94143 (USA).

24. Received for publication March $1,1977$.

25. Accepted for publication May 6, 1977 . 